\title{
Komunikat Komisji do Parlamentu Europejskiego, Rady Europejskiej, Rady, Europejskiego Komitetu Ekonomiczno-Społecznego i Komitetu Regionów pt. Zasady pomocniczości i proporcjonalności: wzmacnianie ich roli w kształtowaniu polityki UE [COM(2018) 703 final] ${ }^{1}$
}

\begin{abstract}
Communication from the Commission to the European Parliament, the European Council, the Council, the European Economic and Social Committee and the Committee of the Regions titled The Principles of Subsidiarity and Proportionality: Strengthening their Role in Shaping the EU policy (COM (2018) 703 final): The communication is a general and preliminary document of a political nature. It is a result of work on the reform of the European Union started in 2017 and the work undertaken in 2017 and 2018 at the initiative of the Commission by the Task Force in the scope of the above principles, in relation to a broadly understood action for better lawmaking. The Communication "identifies ways to strengthen the role of subsidiarity and proportionality in shaping the EU policy. In particular, it initiated follow-up activities of the Commission in relation to the recommendations of the Task Force and ways to highlight areas in which others should act". In the author's opinion, the document is unsatisfactory due to the limited set of suggestions for changes and their superficiality. The communication does not formulate any broader vision of action.
\end{abstract}

Keywords: subsidiarity, European Union, proportionality, communication from the European Commission, better law-making

Słowa kluczowe: pomocniczość, Unia Europejska, proporcjonalność, komunikat Komisji Europejskiej, lepsze stanowienie prawa

Profesor dr hab. nauk prawnych, Wydział Prawa i Administracji Uniwersytetu Kardynała Stefana Wyszyńskiego w Warszawie, ekspert ds. legislacji BAS - cezary.mik@sejm.gov.pl https://orcid.org/0000-0002-6758-1909

1 Opinia na temat Komunikat Komisji do Parlamentu Europejskiego, Rady Europejskiej, Rady, Europejskiego Komitetu Ekonomiczno-Społecznego i Komitetu Regionów pt. Zasady pomocniczości i proporcjonalności: wzmacnianie ich roli $w$ ksztattowaniu polityki UE (COM(2018) 703 final) sporządzona 4 grudnia 2018 r. na zlecenie przewodniczącej Komisji do Spraw Unii Europejskiej; BAS-WAPM 2705/18. 


\section{Opinia merytoryczna}

\section{Przedmiot dokumentu UE}

\section{- Treść dokumentu UE}

1. Przedmiotem opinii jest komunikat Komisji do Parlamentu Europejskiego, Rady Europejskiej, Rady, Europejskiego Komitetu Ekonomiczno-Społecznego i Komitetu Regionów pt. Zasady pomocniczości i proporcjonalności: wzmacnianie ich roli w kształtowaniu polityki UE [COM(2018) 703 final] z 23 października 2018 r. Do opiniowanego komunikatu dołączono dwa załączniki. Pierwszy z nich to dziewięć zaleceń Zespołu zadaniowego ds. pomocniczości i proporcjonalności oraz „robienia mniej, lecz bardziej wydajnie” powołanego przez Przewodniczącego Komisji decyzją z 14 listopada 2017 r., drugi to Wzorcowa tabela służąca do oceny pomocniczości i proporcjonalności w całym cyklu polityki, opracowana także przez Zespół zadaniowy².

Komunikat jest dokumentem o charakterze politycznym. Jest on faktycznie wypadkową prac nad reformą Unii Europejskiej rozpoczętych w 2017 r. ${ }^{3}$ oraz prac podjętych przez Zespół zadaniowy z inicjatywy Komisji w zakresie tytułowych zasad w 2017 i 2018 r. w odniesieniu do szeroko rozumianego działania na rzecz lepszego stanowienia prawa. W komunikacie: określono sposoby wzmocnienia roli zasad pomocniczości i proporcjonalności $w$ kształtowaniu polityki UE. Zainicjowano w nim $w$ szczególności działania następcze Komisji podejmowane $w$ związku z zaleceniami grupy zadaniowej oraz sposoby uwypuklania obszarów, $w$ których powinni działać inni. Komunikat jest opracowaniem ogólnym i wstępnym. W związku z tym Komisja stwierdziła, że: zamierza doprecyzować szczegóły $w$ ramach przegladu lepszego stanowienia prawa w pierwszej połowie 2019 r. - po wystuchaniu opinii wszystkich stron, w których interesie leży lepsze stanowienie prawa.

Ponadto Komisja zauważyła, że 23 października 2018 r., wraz z opiniowanym komunikatem, przyjęła również sprawozdanie roczne za rok 2017 w sprawie pomocniczości i proporcjonalności ${ }^{4}$, a także sprawozdanie roczne za rok 2017 na temat stosunków między Komisją Europejską a parlamentami narodowymi ${ }^{5}$. Dokumenty te nie są jednak przedmiotem niniejszej opinii.

2. Komunikat obejmuje wprowadzenie, refleksję nad znaczeniem zasad pomocniczości i proporcjonalności, rozważania na temat kluczowych elementów

2 C(2017) 7810. Zob. też informacje na stronie Zespołu: https://portal.cor.europa.eu/ subsidiarity/TaskForce/Pages/welcome.aspx.

3 Biała księga w sprawie przyszłości Europy z 1 marca 2017 r., (COM(2017) 2025 final), zob. opinia BAS z 24 kwietnia 2017 r., sygn. BAS-WAPEiM 487/17.

$4 \operatorname{COM}(2018) 490$ final.

$5 \operatorname{COM}(2018) 491$ final. 
lepszego stanowienia prawa, działania mające na celu wzmocnienie roli rozpatrywanych zasad oraz wnioski i zapowiedzi dalszych kroków w związku z konferencją w Bregencji (odbyła się w dniach 15-16 listopada 2018 r.).

3. W komunikacie Komisja podkreśliła, że zasada pomocniczości dotyka istoty tego, czym zajmuje się Unia. Reguluje ona sposób, w jaki wykonywane są kompetencje Unii. Dodała, że kontrola tej zasady ma w istocie charakter polityczny i jest powierzona instytucjom politycznym Unii oraz parlamentom narodowym. Zdaniem Komisji praktyczne znaczenie zasady pomocniczości: polega na określeniu najlepszego poziomu zarzadzania na potrzeby tworzenia i wdrażania polityki. Polemizuje ona też z twierdzeniem, że odwoływanie się do pomocniczości łączy się z wyborem między podjęciem działania na poziomie Unii Europejskiej i jego brakiem. Jak wyjaśnia to Komisja: Pomocniczość oznacza pozostawienie przestrzeni na to, by odpowiedzialność za podjęcie działania wzią na siebie podmiot umiejscowiony na najbardziej odpowiednim poziomie zarzadzania. Państwa członkowskie mają również swobodę działania tam, gdzie nie podejmuje dziatań Unia, a w odniesieniu do danej polityki może okazać się niezbędne podjęcie działań na wszystkich szczeblach zarzadzania. Ogólnie w ocenach Komisji będzie badany unijny wymiar problemów i skutków każdej nowej inicjatywy. Z kolei w nawiązaniu do zasady proporcjonalności Komisja podkreśliła, że jej wpływ na stanowienie prawa oznacza, iż osiąganie celów polityki unijnej ma odbywać się w sposób najprostszy i najmniej kosztowny, bez niepotrzebnej biurokracji: Chodzi o ostrożne dopasowanie intensywności zaproponowanego środka do celu, który ma zostać osiagnięty.

Komisja wskazała, że pomocniczość i proporcjonalność stanowią kluczowe elementy jej podejścia do lepszego stanowienia prawa, które opiera się na trzech procesach: ewaluacji, ocenie skutków i konsultacjach z zainteresowanymi stronami. W tym kontekście Komisja wymieniła swoje dotychczasowe osiągnięcia (wzrost przejrzystości prac, legalności i odpowiedzialności, organizowanie konsultacji publicznych, opracowanie wytycznych dotyczących lepszego stanowienia prawa, utworzenie Rady ds. Kontroli Regulacyjnej, korzystanie z ekspertów platformy REFIT w sferze upraszczania obowiązujących przepisów, zawarcie nowego porozumienia międzyinstytucjonalnego z Parlamentem Europejskim i Radą).

Komisja stwierdziła też, że obecnie dokonuje ona: przegladu funkcjonowania omawianej polityki lepszego stanowienia prawa oraz aktywnie zasiega opinii wszystkich zainteresowanych stron - Celem przeglądu będzie określenie, czy i w jaki sposób nasze narzędzia lepszego stanowienia prawa można wykorzystywać bardziej skutecznie i efektywnie, wzmacniając równocześnie role pomocniczości i proporcjonalności w kształtowaniu przez nas polityki.

4. W nawiązaniu do sprawozdania Zespołu zadaniowego Komisja zwróciła uwagę, że Zespół ten przedstawił jej dziewięć zaleceń wraz z działaniami, które 
mają pomóc w ich wprowadzaniu w życie ${ }^{6}$. Komisja uznała, że ważne są trzy ustalenia: 1) potrzebny jest nowy sposób pracy, aby tworzyć lepsze akty prawne w oparciu o wspólne zrozumienie zasad pomocniczości i proporcjonalności w całym cyklu polityki; 2) potrzebna jest bardziej „aktywna pomocniczość”, która zwiększy skuteczność wyrażania opinii przez władze lokalne i regionalne oraz parlamenty narodowe i która będzie promować większą odpowiedzialność za to, czym zajmuje się Unia; 3) Unia powinna efektywniej wykorzystywać swoje zasoby i określić priorytety swoich działań, ale nie ma powodów, by ponownie przekazać państwom członkowskim kompetencje przyznane na mocy traktatów lub całe obszary polityki. Komisja wyraziła ogólne poparcie dla poglądu Zespołu, zgodnie z którym należy zwiększyć nacisk na stosowanie zasad pomocniczości i proporcjonalności w kształtowaniu polityki Unii Europejskiej w ramach szerszego programu lepszego stanowienia prawa.

5. Komisja określiła też kilka zadań mających na celu wzmocnienie roli zasad pomocniczości i proporcjonalności. Zaliczyła do nich:

- promowanie wspólnego rozumienia zasad pomocniczości i proporcjonalności (w tym kontekście dostrzegła, że protokół nr 2 do traktatów założycielskich dotyczący obu zasad nie zawiera „obrazowych kryteriów”, istniejących jeszcze w protokole do traktatu z Amsterdamu, lecz włączyła je do wytycznych z 2015 r. na temat lepszego stanowienia prawa; Komisja podniosła, że Zespół zadaniowy przedstawił tabelę, będącą załącznikiem nr 2 do omawianego komunikatu, w której Zespół doprecyzował, jak należy przeprowadzać ocenę stosowania interesujących go zasad, i w tym kontekście podniosła, że chociaż obecnie nie wprowadza tej tabeli do swojej praktyki, to jednak w przyszłości zamierza ją włączyć do wytycznych dotyczących lepszego stanowienia prawa i wykorzystywać ją w ramach oceny skutków, ewaluacji i uzgodnień, które towarzyszą projektom prawodawczym; co więcej, Komisja stwierdziła, że: parlamenty narodowe powinny stosować przedstawiona powyżej tabele oceny, która - w stosownych przypadkach - będzie dostosowana do ich celów. Komisja uważa, że zapewni to większy wpływ ich uzasadnionych opinii, ale nie uniemożliwi im wyrażania w ich opiniach innych obaw, które nie dotycza pomocniczości i proporcjonalności; Komisja zwróciła też uwagę na potrzebę szerszego włączania władz lokalnych i regionalnych w procedury stanowienia prawa, zwłaszcza w procedurę prawodawczą; w związku z tym opowiedziała się za zwiększeniem widoczności informacji otrzymywanych od tych władz),

- umożliwienie parlamentom narodowym sprawowania skuteczniejszego nadzoru (Komisja zapowiedziała wyłączenie, po uzyskaniu akceptacji Parlamentu Europejskiego i Rady, okresu świąt Bożego Narodzenia i Nowego Roku

6 Zob. załącznik I do komunikatu oraz sprawozdanie Zespołu z 10 lipca 2018 r., https:// ec.europa.eu/commission/sites/beta-political/files/report-task-force-subsidiarity-proportionality-and-doing-less-more-efficiently_en.pdf. 
z biegu 8-tygodniowego terminu na przekazanie uzasadnionych opinii przez parlamenty narodowe, a także udzielanie zbiorczych odpowiedzi w przypadku, gdy: znaczna liczba parlamentów narodowych zgłosiła podobne obawy, nawet jeżeli próg zastosowania procedury „zóttej kartki” nie zostanie osiagnięty oraz ukierunkowanie ich obaw i określenie propozycji odnoszacych się do większości uwag w rocznych sprawozdaniach $w$ sprawie pomocniczości i proporcjonalności),

- bardziej aktywny udział władz lokalnych i regionalnych (wprowadzenie w wytycznych dotyczących lepszego stanowienia prawa zmian umożliwiających tym władzom wyrażenie obaw co do poszanowania zasad pomocniczości i proporcjonalności),

- poprawę oceny i prezentacji odpowiednich skutków (Komisja zamierza zmienić swoje wytyczne dotyczące lepszego stanowienia prawa w celu podkreślenia znaczenia analizy i oceny oddziaływania terytorialnego, a także przedstawiać: $w$ sposób bardziej przejrzysty swoje oceny pomocniczości, proporcjonalności i informacje o tym, na kogo (i w jaki sposób) maja one wplyw, w swoich ocenach skutków, ewaluacjach i uzasadnieniach),

- ocenę obowiązującego prawodawstwa pod kątem poszanowania zasady pomocniczości (Komisja zamierza w większym zakresie uwzględnić w ramach oceny obowiązującego prawodawstwa pomocniczość, proporcjonalność, gęstość legislacyjną i rolę władz regionalnych i lokalnych, zmodyfikować działanie platformy REFIT w tych zakresach oraz zapewnić, aby w przeprowadzanych ocenach systematycznie odwoływano się do korespondujących z nimi aktów delegowanych i wykonawczych).

Komisja sformułowała również zestaw zagadnień, które powinny stać się przedmiotem ustaleń na konferencji w Bregencji poświęconej zasadzie pomocniczości. Konferencja miała miejsce w listopadzie 2018 r.?

\section{- Geneza dokumentu UE}

Opiniowany komunikat Komisji jest konsekwencją prac podjętych w związku z pracami koncepcyjnymi nad reformą działania Unii Europejskiej, a także trwającymi już od dłuższego czasu wysiłkami zmierzającymi do zapewnienia w jej ramach lepszego stanowienia prawa. W rozpatrywanym zakresie reforma działania Unii Europejskiej wiąże się bowiem $\mathrm{z}$ dążeniem do umocnienia pozycji parlamentów narodowych w procesie integracji europejskiej m.in. przez uznanie ich wpływu na proces prawodawczy przy użyciu zasady pomocniczości. Z kolei sta-

Zob. stronę prezydencji austriackiej, poświęconą konferencji: https://www.eu2018.at/ calendar-events/political-events/BKA-2018-11-16-Subsidiarity-Conf..html, w tym deklarację Przewodniczącego z 16 listopada 2018 r.: https://www.eu2018.at/latest-news/news/11-16-Declaration-by-the-Chair-16.-November-2018.html. 
rania o coraz lepsze stanowienie prawa łączą się m.in. z określeniem znaczenia w tym procesie (zwłaszcza w kontekście tworzenia nowych lub zmiany obowiązujących aktów prawnych) zasad legalności, pomocniczości i proporcjonalności.

Uwzględniając te działania i odwołując się do programu prac Komisji, jej Przewodniczący 14 listopada 2017 r. wydał decyzję, na mocy której powołał Zespół do spraw pomocniczości, proporcjonalności i „robienia mniej, lecz bardziej wydajnie”. Zgodnie z art. 2 pkt 1-3 decyzji, na jego czele stanął pierwszy wiceprzewodniczący Komisji (F. Timmermans), ale w skład Zespołu weszli przedstawiciele parlamentów narodowych (trzech mianowanych przez przewodniczącego COSAC) i Komitetu Regionów (trzech mianowanych przez przewodniczącego Komitetu Regionów) ${ }^{8}$. Członkowie Zespołu działali na zasadzie niezależności osobistej. Musieli też ujawnić Przewodniczącemu ewentualne konflikty interesów, a ten obowiązany był podjąć właściwe środki (art. 5). Wsparciem merytorycznym Zespołu stali się eksperci do spraw prawnych, społecznych, gospodarczych i środowiska (do 3), wybrani przez Zespół na wniosek jego prze-

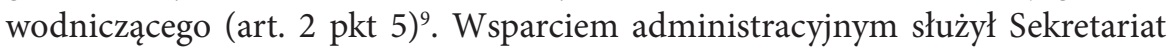
Generalny (oddelegowano 5 urzędników ze służb Rady lub Komisji). Zespół prowadził również otwarty, przejrzysty i regularny dialog z przedstawicielami stowarzyszeń i społeczeństwa obywatelskiego. Mógł w tym celu organizować konsultacje i wysłuchania (art. 4) ${ }^{10}$.

Zespół rozpoczął pracę 1 stycznia 2018 r. (art. 2 pkt 4). Jego sprawozdanie miało być przyjęte w drodze konsensusu, a w razie jego braku większością zwykłą głosów (art. 6 pkt 2). Metody działania, przebieg prac i ich wyniki, łącznie ze sprawozdaniem końcowym, oraz inne dokumenty zostały ujawnione na stronie Zespołu (art. 7).

Zadaniem Zespołu było sporządzenie sprawozdania dla Przewodniczącego Komisji w terminie do 15 lipca 2018 r., które zawierałoby zalecenia w trzech kwestiach: 1) jak lepiej stosować zasady pomocniczości i proporcjonalności w pracach instytucji unijnych, zwłaszcza dotyczące przygotowania i implementacji prawodawstwa Unii i jej polityk; 2) identyfikacji wszelkich dziedzin polityki, w zakresie których kompetencje prawodawcze lub implementacyjne należałoby w całości lub w części zwrócić (redelegować) państwom członkowskim; 3) identyfikacji sposobów lepszego zaangażowania władz regionalnych i lokalnych w przygotowywanie i wprowadzanie w życie polityk unijnych (art. 3).

8 Konferencja Przewodniczących Parlamentu Europejskiego decyzją z 11 stycznia 2018 r. nie przyjęła zaproszenia do udziału Parlamentu w pracy Grupy zadaniowej.

9 Zob. informacje o Grupie Ekspertów w sprawie pomocniczości: https://portal.cor. europa.eu/subsidiarity/whatis/Pages/Subsidiarity-Expert-Group.aspx. Nie należał do niej żaden ekspert z państw członkowskich położonych w Europie Środkowej i Wschodniej.

10 Zob. informacje na ten temat: https://portal.cor.europa.eu/subsidiarity/activities/Pages/Consultations.aspx. 
Na zakończenie swoich prac Zespół przedstawił 10 lipca 2018 r. sprawozdanie pt. „Aktywna pomocniczość. Nowy sposób pracy”. Sformułował w nim dziewięć zaleceń wraz z działaniami o charakterze implementującym. Dotyczą one następujących zagadnień: 1) stosowania (opracowanej przez Zespół) tabeli oceny przez instytucje i organy unijne oraz parlamenty narodowe i regionalne (tabela przewiduje ocenę projektu aktu w całym cyklu polityki; obejmuje ona ocenę co do wyboru podstawy prawnej, poszanowania zasad pomocniczości i proporcjonalności); 2) elastycznego stosowania terminu 8 tygodni na dostarczenie przez parlamenty narodowe opinii w sprawie pomocniczości i odpowiedniego uwzględniania tych opinii w rocznych sprawozdaniach na temat poszanowania zasad pomocniczości i proporcjonalności; 3 ) zmiany protokołu nr 2 dotyczącego zasad pomocniczości i proporcjonalności w zakresie wydłużenia okresu na przekazanie opinii przez parlamenty narodowe do 12 tygodni oraz poszerzenia kontroli o zasadę proporcjonalności i przyznania kompetencji (kontroli podstawy prawnej); 4) działań na rzecz zwiększenia świadomości władz krajowych, regionalnych i lokalnych w zakresie wnoszenia wkładu w kształtowanie polityki na wczesnym etapie, większego zaangażowania władz regionalnych i lokalnych w proces konsultacji (zaleca się też, aby państwa członkowskie postępowały zgodnie z wytycznymi Komisji i angażowały się rzeczywiście we współpracę z władzami regionalnymi i lokalnymi: podczas przygotowywania krajowych programów reform oraz opracowywania $i$ wdrażania reform strukturalnych $w$ ramach europejskiego semestru w celu zwiększenia odpowiedzialności za te reformy i zwiększenia skuteczności ich wdrożenia); 5) zapewnienia przez Komisję, aby w ocenach skutków i ewaluacjach systematycznie uwzględniano oddziaływanie terytorialne i dokonywano jego oceny, o ile jest ono ważne dla władz regionalnych i lokalnych (zaleca się też, aby władze te pomogły w określaniu potencjalnych skutków terytorialnych $\mathrm{w}$ ramach odpowiedzi formułowanych $\mathrm{w}$ toku konsultacji i udzielania informacji zwrotnych na temat planów działania; zaleca się też zmianę wytycznych Komisji dotyczących lepszego stanowienia prawa i zestaw narzędzi w tym zakresie, zajęcie się kwestiami związanymi z wykonywaniem prawa unijnego i unijną wartością dodaną oraz zapewnienie większej widoczności ocen Komisji dotyczących zasad pomocniczości i proporcjonalności i terytorialnego oddziaływania w projektach aktów i w ich uzasadnieniach); 6) stosowania przez Parlament Europejski i Radę tabeli oceny, którą opracował Zespół, w tym w zakresie, w jakim chodzi o kwestie doniosłe dla władz regionalnych i lokalnych, Komisja powinna im zwracać uwagę na opinie, jakie te władze wyraziły po przyjęciu projektów; rządy państw członkowskich i parlamenty narodowe powinny korzystać z opinii i wiedzy władz regionalnych i lokalnych od początku procedury ustawodawczej; zasugerowano też rozważenie zapraszania przedstawicieli tych władz na posiedzenia Parlamentu Europejskiego i Rady oraz organizowanie przesłuchań i wydarzeń w odpowiednich przypadkach; 7) zbadania możliwości połączenia platform REGPEX i IPEX w celu umocnienia kontroli poszanowania zasady 
pomocniczości; 8) opracowania przez Komisję mechanizmu identyfikacji i oceny przepisów pod kątem pomocniczości, proporcjonalności, upraszczania, gęstości legislacyjnej oraz roli władz lokalnych i regionalnych (Komitet Regionów powinien wprowadzić nową sieć ośrodków regionalnych o charakterze pilotażowym w celu ułatwienia przeprowadzania przeglądów wykonywania polityki); 9) rozważenia przez Parlament Europejski, Radę i Komisję zmiany punktu ciężkości prac w niektórych dziedzinach polityki (lepsza implementacja niż inicjowanie nowych aktów prawnych w dziedzinach, w których: istniejący zbiór przepisów jest dopracowany lub został niedawno poddany gruntownym przegladom).

Oceniając prace Zespołu z perspektywy zadań, jakie postawił przed nim Przewodniczący Komisji, należałoby stwierdzić, że Zespół skupił się na zadaniach 1 i 3, pomijając zadanie 2 (kwestia identyfikacji dziedzin polityki Unii Europejskiej, w których należałoby dokonać redelegacji kompetencji na poziom krajowy). Stanowi to poważną wadę sprawozdania. Zaletą sprawozdania jest natomiast dostrzeżenie potrzeby poszerzenia perspektywy oceny aktów unijnych w toku całego cyklu politycznego oraz opracowanie tabeli, która wykracza poza dotychczasowe podejście (aczkolwiek zgodne z obecnym stanem prawnym), ograniczające rolę parlamentów narodowych do kontroli poszanowania zasady pomocniczości.

- Informacja o stanie prawa obowiązującego w Polsce w materii objętej treścią dokumentu UE

W polskim porządku prawnym przepisy dotyczące kontroli stosowania zasady pomocniczości zawarto w ustawie z 8 października 2010 r. o współpracy Rady Ministrów z Sejmem i Senatem w sprawach związanych z członkostwem Rzeczypospolitej Polskiej w Unii Europejskiej (Dz.U. nr 213, poz. 1395; dalej: ustawa kooperacyjna).

\section{Ocena dokumentu UE}

- Ocena społecznych, gospodarczych i finansowych skutków dokumentu UE

Analizowany dokument nie powoduje skutków społecznych, gospodarczych i finansowych dla państw członkowskich ani dla UE. Będąc materiałem o charakterze wstępnym i ogólnym powinien być wszakże postrzegany jako rozpoczynający głębszą debatę na temat stosowania i przestrzegania zasad pomocniczości i proporcjonalności oraz zasady kompetencji przyznanych przez instytucje Unii oraz państwa członkowskie, jak również możliwych zmian traktatowych w tym zakresie.

W tym kontekście budzi on jednak niedosyt ze względu na bardzo ograniczony zestaw propozycji zmian i ich powierzchowność (tylko częściowo uwzględniających zalecenia Zespołu zadaniowego, również częściowo niezadowalających). 
Komunikat nie formułuje żadnej szerszej wizji kierunków działania. Komisja dostrzegła, że obecnie protokół nr 2, dotyczący zasad pomocniczości i proporcjonalności, nie definiuje jednoznacznie (jak to określa „obrazowo”) kryteriów stosowania zasady pomocniczości. Uważa jednak, że włączyła je do swoich wytycznych dotyczących lepszego stosowania prawa. Można mieć jednak co do tego wątpliwości. Komisja zachęca do stosowania tabeli opracowanej przez Zespół zadaniowy. Istotnie, stanowi ona ważne osiągnięcie. Jednak Komisja nie postuluje rewizji traktatów, które umożliwiłyby wszechstronną ocenę aktów unijnych, zgodnie z tabelą (wszak lege artis parlamenty narodowe mogą wypowiadać się jedynie na temat zasady pomocniczości, nawet nie proporcjonalności, nie mówiąc już o podstawie prawnej; w każdym razie pełna kontrola w tym zakresie jest wykluczona, przed Trybunałem Sprawiedliwości nieegzekwowalna). Komisja w żaden sposób nie odnosi się do postulatów wysuwanych przez parlamenty narodowe dotyczące zielonej i czerwonej kartki ani nawet modyfikacji procedury żółtej kartki. Koncentruje się jedynie na zgodzie na zbiorczą reakcję na opinie parlamentów narodowych, których liczba jest znacząca, ale niesięgająca progu uruchamiającego żółtą kartkę. Zupełnie niezadowalające są też jej propozycje dotyczące przeglądu obowiązującego prawodawstwa (jak wspomniano, także Zespół zadaniowy nie wywiązał się w tym zakresie ze swoich zadań). Propozycje dotyczące większego zaangażowania władz regionalnych i lokalnych z kolei powinny być formułowane $\mathrm{z}$ większą roztropnością, biorąc pod uwagę fakt, że - jak to zauważa sama Komisja - istnieją 74 zgromadzenia regionalne, a ponadto 280 regionów i 80 tys. władz lokalnych (milczy się za to na temat Komitetu Regionów jako reprezentanta tych władz). Nacisk na ich rolę razi w zestawieniu z bardzo powściągliwymi sugestiami dotyczącymi wzmocnienia pozycji parlamentów narodowych, do których w końcu adresowane są postanowienia traktatów.

\section{- Ocena zgodności działań UE, o których mowa w dokumencie UE, z zasadą pomocniczości}

Dokument UE nie podlega ocenie co do zgodności z zasadą pomocniczości $\mathrm{w}$ trybie protokołu $\mathrm{nr}$ 2, ponieważ nie jest projektem aktu ustawodawczego UE.

\section{- Ustosunkowanie się do informacji Rady Ministrów}

Komitet ds. Europejskich Rady Ministrów przyjął stanowisko w sprawie komunikatu Komisji 14 listopada 2018 r. Rząd zajął generalnie pozytywne stanowisko wobec komunikatu i zawartych w nim propozycji i kierunków działania. Poparł m.in. postulaty związane ze stosowaniem tabeli opracowanej przez Zespół zadaniowy, szerszym włączeniem władz regionalnych i lokalnych, usprawnieniem procesu oceny skutków czy wzmocnieniem platformy REFIT w odniesieniu do ewaluacji obowiązującego prawodawstwa unijnego.

Jednocześnie rząd odnotował: ostrożne podejście KE do implementacji zasad pomocniczości i proporcjonalności. Zakres propozycji zawartych $w$ komunikacie 
Komisji jest dość ograniczony i nie uwzględnia postulatów dotyczacych wzmocnienia roli parlamentów narodowych $w$ procesie decyzyjnym UE, formułowanych także w Parlamencie RP. Komunikat KE stanowi zestawienie praktycznych rozwiazań mieszczacych się w obecnych ramach traktatowych i mogacych pozytywnie wpłynać na stosowanie istniejących mechanizmów, ale nie zawiera propozycji dotyczacych ewentualnych nowych instrumentów, które realizowałyby postulaty parlamentów narodowych. Odnosi się to $w$ szczególności do ustanowienia mechanizmu czerwonej kartki, który w skuteczny sposób pozwalałby określonej liczbie izb parlamentarnych zablokować prace nad konkretnym projektem aktu legislacyjnego o ile nie zostana $w$ nim uwzględnione zastrzeżenia zgłoszone przez parlamenty narodowe oraz procedury zielonej kartki umożliwiajacej parlamentom narodowym wnoszenie propozycji ustawodawczych oraz rewizji istniejących przepisów. Wzmocnieniu roli parlamentów narodowych służyłoby także usprawnienie mechanizmu żółtej kartki poprzez wydłużenie terminu na przedstawienie uzasadnionych opinii, np. do 16 tygodni. Proponowane przez KE nieuwzględnianie w obowiazujacym terminie 8 tygodni okresu świąt Bożego Narodzenia oraz okresu noworocznego nie jest $w$ tym kontekście wystarczające $i$ nie odpowiada na postulaty parlamentów narodowych.

Rząd wskazał też, że: KE nie odniosła się wprost w komunikacie do rekomendacji grupy zadaniowej dotyczacej poszerzenia zakresu uzasadnionych opinii o ocenę zgodności z zasadą proporcjonalności i ocene podstawy prawnej, choć należy odnotować, ze wypracowana przez grupe zadaniowa modelowa tabela oceny (assessment grid), która Komisja zamierza stosować w swoich pracach i promować wśród parlamentów narodowych uwzględnia już te elementy.

Wreszcie rząd podkreślił, że Komisja: nie odniosła się do problemu nieuwzględniania opinii parlamentów narodowych, nawet w przypadku uruchomienia procedury żółtej kartki, czego przykładem były prace nad rewizja dyrektywy w sprawie delegowania pracowników w ramach świadczenia usług. W ocenie rządu fakt ten negatywnie oddziałuje na poziom zaangażowania parlamentów w proces decyzyjny UE.

\section{Opinia prawna}

\section{Podstawa prawna dokumentu UE}

Komunikat Komisji jest dokumentem UE niebędącym projektem aktu prawnego UE. Zgodnie $\mathrm{z}$ art. 1 protokołu nr $1 \mathrm{w}$ sprawie roli parlamentów narodowych w Unii Europejskiej załączonego do Traktatu o UE i Traktatu o funkcjonowaniu UE jest on dokumentem konsultacyjnym Komisji, przekazywanym parlamentom narodowym.

Brak jest przesłanek, które uniemożliwiałyby przedstawienie przez Komisję komunikatu w omawianym zakresie. 


\section{Skutki prawne dokumentu UE}

Komunikat jest dokumentem UE niebędącym projektem aktu prawnego UE. Nie wywołuje on skutków prawnych w świetle prawa polskiego ani prawa UE.

\section{Kwestie proceduralne}

\section{- Procedura przyjmowania dokumentu UE}

Przyjmowanie komunikatu nie jest związane z zachowaniem określonej, wynikającej z prawa traktatowego, procedury. Dokument UE został przyjęty przez Komisję 23 października 2018 r. Został przesłany do adresatów i parlamentów narodowych. Do Sejmu RP został przekazany 24 października 2018 r. w języku angielskim, a 5 listopada 2018 r. w językach polskim i francuskim.

\section{- Działania Komisji do Spraw Unii Europejskiej}

Komisja do Spraw UE wystąpiła 19 listopada 2018 r. do Rady Ministrów o przedstawienie informacji na temat analizowanego dokumentu w trybie art. 3 ust. 2 ustawy kooperacyjnej. Informacja taka została przekazana 21 listopada $2018 \mathrm{r}$. Komisja do Spraw UE może rozpatrzyć dokument UE w trybie art. 151 ust. 1 regulaminu Sejmu, nie jest w tym zakresie ograniczona terminami, poza tymi, które mogą wynikać z celowości podejmowanych przez nią działań.

\section{Podsumowanie}

- Kontrola przestrzegania zasady pomocniczości dotyczy obszaru istotnych uprawnień parlamentów narodowych w ramach kształtowania polityki i tworzenia prawa Unii Europejskiej.

- Analizowany komunikat, będąc dokumentem o charakterze wstępnym i ogólnym, powinien być postrzegany jako rozpoczynający głębszą debatę na temat stosowania oraz przestrzegania zasad pomocniczości i proporcjonalności oraz zasady kompetencji przyznanych przez instytucje Unii oraz państwa członkowskie, jak również na temat możliwych zmian traktatowych w tym zakresie.

- We wskazanym kontekście komunikat budzi jednak niedosyt ze względu na bardzo ograniczony zestaw propozycji zmian i ich powierzchowność. Uwzględniają one tylko częściowo zalecenia Zespołu zadaniowego ds. pomocniczości i proporcjonalności i „robienia mniej, lecz bardziej wydajnie”. 